\title{
DETERMINANTY WPROWADZANIA OPŁATY REKLAMOWEJ
}

\section{THE DETERMINANTS OF ADVERTISING FEE INTRODUCTION}

\section{Streszczenie}

W opracowaniu podjęto próbę ustalenia determinantów wprowadzenia opłaty reklamowej. Ta nowa danina publiczna wprowadzona w 2015 r. może stanowić istotne narzędzie wspomagające funkcjonowanie gmin. Ustawodawca wprowadzając tę opłatę nie tylko określił jej konstrukcję normatywną, ale jednocześnie powiązał tę daninę publiczną z działaniami na rzecz kształtowania krajobrazu. Stąd też już w samej konstrukcji tej opłaty, jak również w obszarze jej stosowania istotne jest dostrzeżenie tych determinantów, które mają nie tylko „wymiar podatkowy”, ale także „pozapodatkowy”.

Słowa kluczowe: opłata reklamowa; daniny publiczne; podatki i opłaty lokalne.

The aim of the article is to attempt to establish determinants of advertising fee introduction. This new form of public tribute introduced in 2015 may constitute an important tool to support the functioning of local authorities. The legislator introducing above fee established not only its normative construction, but also linked this public tribute with efforts towards landscaping. Therefore already both in the construction of this fee and in the field of its application decisive are such determinants, which have not only "tax dimension" but also "extra-tax dimension".

Keywords: advertising fee; public levies; local fees and taxes. 


\section{Wprowadzenie}

Ochrona podstawowych, konstytucyjnych dóbr związanych m.in. z ochroną dziedzictwa narodowego i ochroną środowiska, oparta o koncepcję zrównoważonego rozwoju ${ }^{1,2}$ spowodowała konieczność podjęcia przez ustawodawcę zdecydowanego, ukierunkowanego działania, zmierzającego w istocie do wyhamowania procesów postępującej degradacji przestrzeni publicznej, wskutek m.in. ekspansji wszelakiego rodzaju, wielkości i struktury nośników reklam i wprowadzenia podstaw skutecznego nią zarządzania.

Zaburzenie ładu przestrzennego, rozumianego jako swoistego rodzaju ukształtowanie przestrzeni, które tworzy harmonijną całość oraz uwzględnia w uporządkowanych relacjach wszelkie uwarunkowania i wymagania funkcjonalne, społeczno-gospodarcze, środowiskowe, kulturowe oraz kompozycyjno-estetyczne ${ }^{3}$ niewątpliwie prowadzić może do zachwiania ochrony wskazanych wyżej konstytucyjnych dóbr a co najmniej do ich „nadwyrężenia”. Powyższe związane jest z określonymi warunkami miejscowymi, choć bezsprzecznie przede wszystkim uzależnione od stopnia urbanizacji terenu, ewentualnie od jego atrakcyjności np. turystycznej, wpływającego de facto na wielkość populacji będącej odbiorcą reklamy.

Realizacja celów związanych z promowaniem ochrony, gospodarki i planowaniem krajobrazu, stanowiła wyraz przyjętych przez Rzeczpospolitą Polską zobowiązań określonych w Europejskiej Konwencji Krajobrazowej, sporządzonej przez państwa członkowskie Rady Europy we Florencji 20 października 2000 r. ${ }^{4}$ W Konwencji przyjęto, „w trosce o osiągnięcie trwałego i zrównoważonego rozwoju opartego na zrównoważonych i harmonijnych relacjach

1 Definicja legalna zrównoważonego rozwoju została zawarta w art. 3 pkt 50 ustawy z dnia 27 kwietnia 2001 r. Prawo ochrony środowiska (tekst jedn. Dz.U. z 2017 r., poz. 519 ze zm.). Przez zrównoważony rozwój - rozumie się taki rozwój społeczno-gospodarczy, w którym następuje proces integrowania działań politycznych, gospodarczych i społecznych, z zachowaniem równowagi przyrodniczej oraz trwałości podstawowych procesów przyrodniczych, w celu zagwarantowania możliwości zaspokajania podstawowych potrzeb poszczególnych społeczności lub obywateli zarówno współczesnego pokolenia, jak i przyszłych pokoleń.

$2 \quad$ Art. 5 Konstytucji RP z dnia 2 kwietnia 1997 r. (Dz.U. Nr 78, poz. 483 ze zm.).

3 Art. 2 pkt 1 ustawy z dnia 27 marca 2003 r. o planowaniu i zagospodarowaniu przestrzennym (tekst jedn. Dz.U. z 2016 r., poz. 778), dalej: u.z.p.

4 Europejska Konwencja Krajobrazowa podana do publicznej wiadomości przez Prezydenta RP w Dz.U. z 2006 r. Nr 14, poz. 98; dalej: Konwencja. 
pomiędzy potrzebami społecznymi, działalnością gospodarczą i środowiskiem" konieczność wdrożenia określonych działań przez państwa członkowskie, mając na uwadze m.in. fakt, że ,krajobraz przyczynia się do tworzenia kultur lokalnych oraz że jest on podstawowym komponentem europejskiego dziedzictwa przyrodniczego i kulturowego, przyczyniając się do dobrobytu ludzi i konsolidacji europejskiej tożsamości".

Celem publikacji jest wyodrębnienie i przedstawienie determinantów wprowadzenia do systemu prawa, systemu prawa podatkowego, a ściślej do ustawy $\mathrm{z}$ dnia 12 stycznia $1991 \mathrm{r}$ o podatkach i opłatach lokalnych ${ }^{5}$ nowej daniny publicznoprawnej, tj. opłaty reklamowej. Ustawodawca wprowadzając tę opłatę, nie tylko określił jej konstrukcję normatywną, ale jednocześnie powiązał tę daninę publiczną z działaniami na rzecz kształtowania krajobrazu. Stąd też już w samej konstrukcji tej opłaty, jak również w obszarze jej stosowania istotne jest poszukiwanie i dostrzeżenie tych determinantów, które mają nie tylko „wymiar podatkowy” (fiskalny), ale także ,pozapodatkowy”(pozafiskalny).

Przyjęta w publikacji hipoteza sprowadza się do twierdzenia, iż do podstawowych i priorytetowych determinantów wprowadzenia opłaty reklamowej należą determinanty pozapodatkowe (pozafiskalne).

Realizacja celu publikacji uzasadnia konieczność przyjęcia pojęcia determinantów wprowadzenia opłaty reklamowej. Determinanty te to czynniki mające walor prawny jak i pozaprawny, które stanowią nie tylko podstawę ale i motywują do wprowadzenia opłaty reklamowej do systemu prawa.

Niewątpliwie znajomość określonych determinantów wprowadzenia opłaty reklamowej umożliwi ustalenie zasadności wykorzystania tego instrumentu podatkowego dla realizacji zamierzonych przez ustawodawcę celów w tym ustalenie roli opłaty reklamowej jako instrumentu odziaływania na określone podmioty. Omawiany przypadek jest bowiem doskonałym przykładem możliwości przypomnienia o powtarzającym się w poszczególnych dyskusjach pytaniu o granice nakładania danin publicznych ${ }^{6}$.

Ustawą z dnia 24 kwietnia 2015 r. o zmianie niektórych ustaw w związku ze wzmocnieniem narzędzi ochrony krajobrazu ${ }^{7}$ dokonano $\mathrm{w}$ systemie prawa polskiego zmian stanowiących poniekąd w ograniczonym zakresie realizację

Tekst jedn. Dz.U. z 2016 r., poz. 716, dalej: u.p.o.l.

Zob. szerzej na temat granic opodatkowania R. Mastalski, Prawo podatkowe, Warszawa 2016, str. 4-6. Por. również z: R. Mastalski, Tworzenie prawa podatkowego a jego stosowanie, Warszawa $2016 \mathrm{r}$.

7 Dz.U. z 2015 r., poz. 774, zwaną dalej: ustawą krajobrazową. 
przyjętych przez Polskę zobowiązań umożliwiających realizację założonych w Konwencji celów związanych z ochroną krajobrazu jego gospodarką i planowaniem. „Poniekąd” ponieważ sam projektodawca w uzasadnieniu do ustawy wskazał, iż „ustawa ta nie aspiruje do roli kompleksowego wprowadzenia rozwiązań przewidzianych Europejską Konwencją Krajobrazową. Podstawowym założeniem, które legło u podstaw opracowania projektu było zminimalizowanie zakresu dokonywanych zmian legislacyjnych przy jednoczesnym uzyskaniu znaczącego efektu z punktu widzenia ochrony krajobrazu"8.

Zmiany dotyczyły m.in. ustawy z dnia 7 lipca 1994 r. Prawo budowlane ${ }^{9}$, ustawy z dnia 21 marca 1985 r. o drogach publicznych ${ }^{10}$ ale przede wszystkim ustawy z dnia 27 marca 2003 r. o planowaniu i zagospodarowaniu przestrzennym oraz ustawy z dnia 12 stycznia $1991 \mathrm{r}$. o podatkach i opłatach lokalnych.

\section{Determinanty pozafiskalne}

Wskazaną już ustawą krajobrazową wprowadzono do ustawy o planowaniu i zagospodarowaniu przestrzennym pojęcie krajobrazu, przez który należy rozumieć postrzeganą przez ludzi przestrzeń, zawierającą elementy przyrodnicze lub wytwory cywilizacji, ukształtowaną w wyniku działania czynników naturalnych lub działalności człowieka ${ }^{11}$. W odniesieniu do wskazanej wyżej Konwencji to krajobraz jest wartością chronioną i nadrzędną dla wszelkich pozostałych elementów wprowadzanych regulacji. Właściwe pojęcie krajobrazu należy rozpatrywać poprzez identyfikowany w ustawie o planowaniu i zagospodarowaniu przestrzennym ład przestrzenny i zrównoważony rozwój.

Elementami, których nadmierna ekspansja niekorzystnie wpływa na tak określone nadrzędne wartości nie jest sama w sobie reklama ale jej nośniki materialne, a zatem określone w ustawie tablice reklamowe i urządzenia reklamowe przeznaczone lub służące ekspozycji reklamy wraz z ich elementami konstrukcyjnymi i zamocowaniami. To nośniki materialne reklamy mogą prowadzić do zaburzenia ładu przestrzennego i przestrzeni publicznej. Powyższe jest szczególnie zauważalne w dużych aglomeracjach jak również

\footnotetext{
8 Uzasadnienie projektu ustawy o zmianie niektórych ustaw w związku ze wzmocnieniem narzędzi ochrony krajobrazu, Sejm VII kadencji, druk nr 1525.

9 Tekst jedn. Dz.U. z 2016 r., poz. 290.

10 Tekst jedn. Dz.U. z 2016 r., poz. 1440.

11 Art. 2 pkt. 16e u.z.p.
} 
miejscowościach typowo turystycznych, których walory krajobrazowe są ukryte za szpalerami nośników reklam.

Stosownie do art. 2 pkt. 16a u.z.p. przez reklamę należy rozumieć upowszechnianie w jakiejkolwiek wizualnej formie informacji promującej osoby, przedsiębiorstwa, towary, usługi, przedsięwzięcia lub ruchy społeczne. Reklama stanowi zatem zwizualizowaną formę informacji, której celem jest rozpowszechnienie informacji o podmiotach, przedmiotach, cechach określonych usług czy towarów.

Wskazanemu w przepisie upowszechnianiu służą nośniki reklamy identyfikowane w ustawie jako tablice reklamowe i urządzenia reklamowe. Tablicą reklamową jest przedmiot materialny przeznaczony lub służący ekspozycji reklamy wraz z jego elementami konstrukcyjnymi i zamocowaniami, o płaskiej powierzchni służącej ekspozycji reklamy, w szczególności baner reklamowy, reklama naklejana na okna budynków i reklamy umieszczane na rusztowaniu, ogrodzeniu lub wyposażeniu placu budowy, z wyłączeniem drobnych przedmiotów codziennego użytku wykorzystywanych zgodnie $\mathrm{z}$ ich przeznaczeniem (art. 2 pkt 16b u.z.p.). Urządzeniem reklamowym jest natomiast zgodnie $\mathrm{z}$ art. 2 pkt 16c u.z.p. przedmiot materialny przeznaczony lub służący ekspozycji reklamy wraz z jego elementami konstrukcyjnymi i zamocowaniami, inny niż tablica reklamowa, z wyłączeniem drobnych przedmiotów codziennego użytku wykorzystywanych zgodnie z ich przeznaczeniem.

Z uwagi na fakt, iż w zasadzie ,właścicielem” przestrzeni publicznej jak również zobowiązanym do ochrony ładu przestrzennego ${ }^{12}$ jest gmina jako jednostka samorządu terytorialnego ${ }^{13}$ podjęcie decyzji o skorzystaniu a następnie o wdrożeniu swoistego rodzaju ochrony uregulowanego przez ustawodawcę sytemu, pozostawiono gminom.

Rada gminy, na podstawie kompetencji zawartej w art. 37a ust. 1-3 ustawy może ustalić w formie uchwały zasady i warunki sytuowania obiektów małej architektury, tablic reklamowych i urządzeń reklamowych oraz ogrodzeń, ich gabaryty, standardy jakościowe oraz rodzaje materiałów budowlanych, z jakich mogą

12 Art. 7 ust. 1 pkt 1 ustawy z dnia 8 marca 1990 r. o samorządzie gminnym (tekst jedn. Dz.U. z 2016 r., poz. 446).

13 Kształtowanie i prowadzenie polityki przestrzennej na terenie gminy, w tym uchwalanie studium uwarunkowań i kierunków zagospodarowania przestrzennego gminy oraz miejscowych planów zagospodarowania przestrzennego, $\mathrm{z}$ wyjątkiem morskich wód wewnętrznych, morza terytorialnego i wyłącznej strefy ekonomicznej oraz terenów zamkniętych, należy do zadań własnych gminy (art. 3 ust. 1 u.z.p.). 
być wykonane. W odniesieniu do szyldów, przez które zgodnie z art. 2 pkt. 16d u.z.p. należy rozumieć tablice reklamowe lub urządzenia reklamowe informujące o działalności prowadzonej na nieruchomości, na której te tablice reklamowe lub urządzenia reklamowe się znajdują, w przedmiotowej uchwale określa również zasady i warunki ich sytuowania, gabaryty oraz liczbę szyldów, które mogą być umieszczone na danej nieruchomości przez podmiot prowadzący na niej działalność. Ustawodawca podkreślił również uprawnienia gminy odnoszące się do możliwości podjęcia decyzji o zakazie sytuowania ogrodzen ${ }^{14}$ oraz tablic reklamowych i urządzeń reklamowych. Powyższe jednak nie dotyczy z oczywistych względów szyldów. Podjęta przez organ stanowiący uchwała jest aktem prawa miejscowego.

W ustawie o planowaniu i zagospodarowaniu przestrzennym nie wskazano na możliwość wykorzystania dla celów ochrony ładu przestrzennego, przestrzeni publicznej czy też krajobrazu określonego narzędzia, w tym instrumentu regulowanego w ustawie o podatkach i opłatach lokalnych.

Pojęcie opłaty reklamowej w ustawie o planowaniu i zagospodarowaniu przestrzennym pojawia się jedynie w kontekście ustalania wysokości kar pieniężnych dla podmiotów, które umieściły tablicę reklamową lub urządzenie reklamowe niezgodnie z przepisami uchwały, o której mowa w art. 37a ust. 1 ustawy. W zależności bowiem od tego czy rada wprowadziła opłatę reklamową regulowaną art. 17a ustawy o podatkach i opłatach lokalnych czy też nie ustawodawca na gruncie ustawy o zagospodarowaniu przestrzennym zróżnicował podstawy naliczania wysokości kar pieniężnych ${ }^{15}$. Tym samym prawne podstawy ochrony wskazanych wyżej wartości uregulowane zostały bezpośrednio ${ }^{16}$ w dwóch ustawach: ustawie o planowaniu i zagospodarowaniu przestrzennym oraz ustawie o podatkach i opłatach lokalnych. Skorzystanie przez gminę $\mathrm{z}$ instrumentu regulowanego ustawą podatkową uzależnione jest przy tym od podjęcia uchwały w przedmiocie zasad i warunków sytuowania obiektów małej architektury, tablic reklamowych i urządzeń reklamowych oraz ogrodzeń, ich gabaryty, standardy jakościowe oraz rodzaje materiałów budowlanych, z jakich mogą być wykonane.

Rozpatrując wprowadzoną przez ustawodawcę do ustawy o podatkach i opłatach lokalnych opłatę reklamową należy w pierwszej kolejności

\footnotetext{
Z zastrzeżeniem art. 37a ust. 8 u.z.p.

Art. 37d ust. 8 i 9 u.z.p.

16 Pośrednio można wskazać bowiem wiele ustaw, które wpływają zarówno od strony ustrojowej jak i materialnej na system ochrony szeroko rozumianej przestrzeni publicznej, np. ustawa o samorządzie gminnym, ustawa Prawo ochrony środowiska itd.
} 
zastanowić się nad determinantami jej wprowadzenia. Zgodnie z uzasadnieniem do projektu ustawy krajobrazowej opłata stanowić ma udostępnione przez ustawodawcę narzędzie do realizacji celów związanych z ochroną przestrzeni publicznej (krajobrazu). Narzędzie, z którego gmina będzie mogła skorzystać w celu porządkowania oraz zarządzania przestrzenią publiczną. Przekazanie organom stanowiącym gminy kompetencji do regulacji, w ustawowo zakreślonym wymiarze, spowodowane głównie jest (i słusznie) uwzględnieniem warunków lokalnych, wpływających na potrzeby konkretnych gmin. Inaczej prawdopodobnie do sprawy zarzadzania krajobrazem, podejdą organy stanowiące Zakopanego, a inaczej przykładowo miasta wysoce zindustrializowanego, uprzemysłowionego. Odmienną politykę w tym przedmiocie z pewnością będą miały gminy miejskie a inną gminy typowo rolnicze.

Ustawodawca podatkowy wyraźnie wskazał na fakultatywny charakter opłaty reklamowej. Powyższe wynika bezpośrednio z użycia przez ustawodawcę sformułowania w art. 17a u.p.o.l., odnoszącego się do możliwości wprowadzenia tej opłaty. Zgodnie z art. 17a u.p.o.l. rada gminy może wprowadzić opłatę reklamową od umieszczonych tablic i urządzeń reklamowych. Wprowadzenie a następnie pobór opłaty reklamowej uzależnione jest jednak od uprzedniego uregulowania przez radę gminy zasad i warunków sytuowania obiektów małej architektury, tablic reklamowych i urządzeń reklamowych oraz ogrodzeń a zatem uchwały podjętej w oparciu o ustawę o planowaniu i zagospodarowaniu przestrzennym. Skoro opłata reklamowa stanowić ma swoistego rodzaju narzędzie do porządkowania przestrzeni krajobrazowej nie może istnieć bez podstawowego aktu umożliwiającego w następstwie jego uchwalenia również wprowadzenie do systemu prawa lokalnego opłaty reklamowej.

Z powyższych ustaleń wynika jednoznacznie, iż czynnikami pozafiskalnymi, motywującymi ustawodawcę do wprowadzenia do systemu prawa opłaty reklamowej (determinantami jej wprowadzenia), były przede wszystkim:

- przyjęte przez Rzeczpospolitą Polską w Europejskiej Konwencji Krajobrazowej zobowiązania w zakresie wdrożenia określonych rozwiązań w zakresie ochrony krajobrazu,

- konieczność wprowadzenia narzędzia do porządkowania przestrzeni publicznej, a zatem środka do zniwelowania skutków obecnego stanu degradacji przestrzeni publicznej,

- konieczność wprowadzenia narzędzia do zarządzania przestrzenią publiczną, rozumianego jako środek umożliwiający „dystrybucję” tej przestrzeni. 


\section{Determinanty fiskalne}

W każdym przypadku, w którym ustawodawca wykorzystuje określone narzędzia prawne $\mathrm{w}$ celu ochrony określonych dóbr powstaje pytanie o zasadność ich stosowania a zarazem adekwatność zastosowanego narzędzia do ochrony danego dobra. Również i w przedmiotowym przypadku uzasadnione jest pytanie, czy wprowadzenie do systemu prawa narzędzia służącego wg zamierzeń ustawodawcy zarządzaniu przestrzenią publiczną, narzędzia regulowanego w ustawach podatkowych, jest słuszne nie tylko z punktu widzenia zarządzania tą przestrzenią ale również z uwagi na określony prawny charakter tego narzędzia. Odpowiedź na tak postawione pytanie wymaga w pierwszej kolejności ustalenia charakteru prawnego opłaty reklamowej.

Opłaty stanowią daniny publicznoprawne aczkolwiek często pomimo posłużenia się przez ustawodawcę wyrażeniem „opłata” wątpliwym jest w pełni przyznanie im takiego charakteru. Opłata jest daniną publicznoprawną posiadającą większość cech podatku, tj. posiada charakter publicznoprawny, przymusowy, bezwrotny, z tym że w przeciwieństwie do podatku jest świadczeniem odpłatnym.

Jak wskazuje się w literaturze „opłata publiczna opiera się na trzech elementach:

1. jest nakładana przymusowo przez korporacje publicznoprawne (państwo i samorząd terytorialny),

2. w przeciwieństwie do grzywien i kar pieniężnych jest nakładana w celu pokrycia publicznych potrzeb finansowych,

3. stanowi rodzaj świadczenia wzajemnego na rzecz korporacji publicznoprawnych w zamian za oferowane przez nie świadczenia lub urządzenia, które w całości lub w części w sposób szczególny służą jednostkom lub określonym grupom osób, przysparzając im korzyści"17.

Ponadto wskazuje się, iż gdy, ,świadczenie występujące pod nazwą opłaty, nie zobowiązuje podmiotu publicznoprawnego do żadnego wzajemnego zachowania się, taka opłata ma $\mathrm{w}$ istocie charakter nieodpłatny i nabiera cech podatku"18.

17 C. Kosikowski, [w:] C. Kosikowski. L. Etel, J. Brolik, R. Dowgier, P. Pietrasz, M. Popławski, S. Presnarowicz, W. Stachurski, Ordynacja Podatkowa. Komentarz, Warszawa 2013, s. 38.

18 E. Ruśkowski, J.M. Salachna, Ustawa o dochodach jednostek samorzadu terytorialnego. Komentarz, Warszawa 2004, s. 86; zob. również A. Huchla, Pojęcie i rodzaj opłat 
Przyczyn takiego stanu poszukiwać można w szeroko rozumianej ,,psychologii podatkowej”, zmierzającej do skuteczności behawioralnej wprowadzanych norm wyznaczających określone obowiązki dla ich adresatów a poprzez to zwiększenie akceptowalności wprowadzanych ciężarów daninowych ${ }^{19}$.

Rozważając charakter prawny opłaty w stosunku do podatku zwrócić należy uwagę, iż w istocie opłata reklamowa, jakkolwiek nakładana w drodze wykorzystania przez organy gminy swoich kompetencji określonych w ustawie o podatkach i opłatach lokalnych a zatem w drodze wykorzystania przekazanego przez ustawodawcę władztwa podatkowego, nie wyczerpuje cech charakterystycznych, właściwych dla tego rodzaju danin publicznych a zatem cech odpłatności. Nietrudno zauważyć, iż ustawodawca nie przewiduje po stronie gminy żadnych wzajemnych świadczeń na rzecz wnoszącego opłatę. Nie chodzi tu przy tym o ekwiwalentność, która jest cechą stosunków cywilnoprawnych ale o swoistego rodzaju rekompensatę związaną z dolegliwością uiszczenia opłaty. Tym samym cechy opłaty reklamowej zbliżają niewątpliwe tą daninę publiczną do podatku w rozumieniu ustawy z dnia 29 sierpnia $1997 \mathrm{r}$. Ordynacja podatkowa ${ }^{20}$.

Opłaty bowiem, jak wskazał Trybunał Konstytucyjny w wyroku sygn. akt P 6/02 z dnia 10 grudnia 2002 r. pobierane są „w związku z wyraźnie wskazanymi usługami i czynnościami organów państwowych lub samorządowych, dokonywane w interesie konkretnych podmiotów. Stanowią zatem swoistą zapłatę za uzyskanie zindywidualizowanego świadczenia oferowanego przez podmiot prawa publicznego"21.

Tak postrzegany charakter opłaty ewidentnie wskazuje na konieczność rozważenia opłaty reklamowej jako elementu pokrycia publicznych potrzeb finansowych.

Stworzenie przez ustawodawcę podstaw prawnych do zarządzania przestrzenią publiczną stawia bowiem m.in. pytanie o koszty funkcjonowania systemu związanego z tym zarządzaniem. Czy opłata reklamowa ma jedynie na celu umożliwienie samorządom odpowiedniej dystrybucji tej przestrzeni wskutek

publicznych, [w:] R. Mastalski, E. Fojcik-Mastalska (red.), Prawo finansowe, Warszawa 2013, s. 465 i 470.

19 Zob. również J. Gliniecka, Fiskalne i pozafiskalne funkcje opłat jako władczej formy dochodów publicznych, [w:] W. Miemiec (red.), Księga jubileuszowa profesora Ryszarda Mastalskiego. Stanowienie i stosowanie prawa podatkowego, Wrocław 2009, s. 163-169.

20 Tekst jedn. Dz.U. z 2017 r., poz. 201.

21 „Orzecznictwo Trybunału Konstytucyjnego Zbiór Urzędowy” 2002, nr 7, poz. 91. 
wprowadzania określonych lokalnych regulacji i wysokości opłat z tytułu umieszczania tablic reklamowych i urządzeń reklamowych w tej przestrzeni, czy też ma stanowić również wynagrodzenie gminy związane $\mathrm{z}$ organizacją tegoż systemu? Wydaje się, że odpowiedź na drugie pytanie jest również pozytywna. Jakkolwiek w uzasadnieniu projektu wskazano, że „możliwość pozyskania dodatkowych dochodów powinna przysługiwać jedynie tym gminom, w których podejmowane są działania w kierunku uporządkowania przestrzeni publicznej; opłata za reklamy ma stanowić jedno z narzędzi takiego porządkowania, nie zaś źródło uzyskania łatwego dochodu" niewątpliwie trudno nie uznać, iż wprowadzenie tej opłaty ma również na celu zrównoważanie po stronie dochodów budżetu wydatków gminy związanych z organizacją ochrony krajobrazu w tym wydatków związanych z czynnościami organu podatkowego gminy. Wprowadzenie do systemu podatkowego opłaty reklamowej i jej niewątpliwie fiskalny charakter może z drugiej strony zdeterminować gminy do wprowadzenia uchwał, o których mowa w ustawie o zagospodarowaniu przestrzennym, a zatem tych związanych z określaniem warunków i zasad sytuowania tablic i urządzeń reklamowych.

Chęć skorzystania przez gminy z dodatkowego źródła dochodów niewątpliwie uzależniona jest przy tym od stopnia atrakcyjności reklamowej określonych miejscowości i mieszkańców tych miejscowości dla potencjalnych reklamodawców. Atrakcyjności w rozumieniu stopnia możliwości absorbcji konsumenckiej wpływającej na wielkość popytu określonych dóbr.

Przedmiotem opłaty reklamowej są tablice reklamowe lub urządzenia reklamowe umieszone na nieruchomościach lub obiektach budowlanych.

Konstruując przedmiot opłaty reklamowej ustawodawca nie uregulował tych pojęć w ustawie podatkowej ale zastosował w art. 1a ust. 1 pkt 3a u.p.o.l. odesłanie do pojęć przyjętych na gruncie ustawy o planowaniu i zagospodarowaniu przestrzennym. W ten sposób powiązał ściśle ze sobą przedmiotowe akty normatywne.

Opłatę reklamową pobiera się od:

1. właścicieli nieruchomości lub obiektów budowlanych, z wyłączeniem nieruchomości gruntowych oddanych w użytkowanie wieczyste,

2. użytkowników wieczystych nieruchomości gruntowych,

3. posiadaczy samoistnych nieruchomości lub obiektów budowlanych, 
4. posiadaczy nieruchomości lub ich części albo obiektów budowlanych lub ich części, stanowiących własność Skarbu Państwa lub jednostki samorządu terytorialnego, jeżeli posiadanie:

a. wynika z umowy zawartej z właścicielem, Agencją Nieruchomości Rolnych ${ }^{22}$ lub $\mathrm{z}$ innego tytułu prawnego,

b. jest bez tytułu prawnego

- jeżeli na tych nieruchomościach lub obiektach budowlanych znajdują się tablice reklamowe lub urządzenia reklamowe, niezależnie od tego czy na tablicy reklamowej lub urządzeniu reklamowym eksponowana jest reklama.

W sytuacji, w której nieruchomość lub obiekt budowlany, na których zlokalizowana jest tablica reklamowa lub urządzenie reklamowe, jest przedmiotem współwłasności lub pozostaje w posiadaniu dwóch lub więcej osób obowiązek w zakresie wniesienia opłaty reklamowej ciąży solidarnie odpowiednio na wszystkich współwłaścicielach lub współposiadaczach.

Ustawodawca wprowadził wyłączenie poboru opłaty w sytuacjach, w których tablice reklamowe lub urządzenia reklamowe:

1. nie są widoczne z przestrzeni dostępnych publicznie;

2. stanowią szyld, o ile jest on zgodny z zasadami i warunkami sytuowania obiektów małej architektury, tablic reklamowych i urządzeń reklamowych oraz ogrodzeń;

3. są realizacją obowiązku nałożonego przepisami prawa;

4. służą wyłącznie do upowszechniania informacji:

a. trwale upamiętniającej osoby, instytucje lub wydarzenia,

b. charakterze religijnym, związanym z działalnością kościołów lub innych związków wyznaniowych, jeżeli tablica reklamowa lub urządzenie reklamowe sytuowane są w granicach terenów użytkowanych jako miejsca kultu i działalności religijnej oraz cmentarzy.

Zgodnie z art. 17b ust. 1-4 u.p.o.l. opłata reklamowa składa się z części stałej i części zmiennej. Część stała ma zryczałtowaną wysokość niezależną od pola powierzchni tablicy reklamowej lub urządzenia reklamowego służącego ekspozycji reklamy. Część zmienna natomiast uzależniona jest od wielkości

22 Art. $17 \mathrm{a}$ ust. 3 pkt 4 lit. a zmieniony zostanie z dniem 1 września 2017 r. przez art. 6 ustawy z dnia 10 lutego 2017 r. Przepisy wprowadzające ustawę o Krajowym Ośrodku Wsparcia Rolnictwa (Dz.U. z 2017 r., poz. 624). Zmiana związana jest ze zniesieniem Agencji Nieruchomości Rolnych oraz utworzeniem w jej miejsce Krajowego Ośrodka Wsparcia Rolnictwa. 
pola powierzchni tablicy lub urządzenia reklamowego służących ekspozycji reklamy. Ustawodawca wprowadził również unormowanie pozwalające na wyliczenie pola powierzchni służącej ekspozycji reklamy w sytuacji urządzenia reklamowego o skomplikowanym kształcie. Wskazał, iż w takim przypadku wysokość opłaty zależy od pola powierzchni bocznej prostopadłościanu opisanego na urządzeniu reklamowym.

Z powyższego bezsprzecznie zatem wynika, iż do czynników fiskalnych determinujących wprowadzenie opłaty reklamowej można zaliczyć:

- potrzeby wydatkowe gminy związane z organizacją systemu ochrony krajobrazu poprzez właściwą organizację a tym samym również ochronę przestrzeni publicznej,

- możliwość uzyskania dodatkowych dochodów budżetowych i przeznaczenia ich na rosnące potrzeby wspólnoty samorządowej, w szczególności w obliczu ograniczonych możliwości zadłużania się samorządów z uwagi na konieczność zachowania relacji, o której mowa w art. 243 ustawy z dnia 27 sierpnia 2009 r. o finansach publicznych ${ }^{23}$.

\section{Wnioski}

Zaprezentowane powyżej determinanty wprowadzenia opłaty reklamowej pozwalają uznać za prawdziwą hipotezę, iż do podstawowych i priorytetowych determinantów wprowadzenia opłaty reklamowej należą determinanty pozapodatkowe (pozafiskalne). Opłata reklamowa ma w zasadzie służyć swoistego rodzaju ograniczeniu ekspansji tablic reklamowych i urządzeń reklamowych w przestrzeni publicznej. Drugoplanowe w związku z tym są względy fiskalne związane z możliwością uzyskania przez gminy dodatkowego źródła dochodu w sytuacji wprowadzenia na terenie gminy opłaty reklamowej. Wielkość i możliwość uzyskania określonych wpływów budżetowych uzależniona jest bowiem, jak już zaznaczono, od rodzaju gminy.

Otwarte jednak pozostaje pytanie związane z wykorzystaniem przez ustawodawcę do określonych celów związanych z ochroną krajobrazu narzędzia o charakterze typowo podatkowym. Słuszne byłoby bowiem umożliwienie gminie stosownej reglamentacji przestrzeni publicznej wskutek wydawania w trybie administracyjnym określonych pozwoleń na umieszczenie tablic reklamowych lub urządzeń reklamowych w określonej przestrzeni publicznej

23 Tekst jedn. Dz.U. z 2016 r., poz. 1870 ze zm. 
i pobierania w związku z tym opłat związanych z określonymi czynnościami. Taki system z pewnością byłby o wiele tańszy od obecnie wprowadzonego, co jest konsekwencją daninowego charakteru prawnego wskazanej opłaty reklamowej i związanych z tym wydatków na jego funkcjonowanie w tym na czynności egzekucyjne.

\section{Literatura}

1. Gliniecka J., Fiskalne i pozafiskalne funkcje opłat jako władczej formy dochodów publicznych, [w:] W. Miemiec (red.), Księga jubileuszowa profesora Ryszarda Mastalskiego. Stanowienie i stosowanie prawa podatkowego, Wrocław 2009.

2. Huchla A., Pojęcie i rodzaj opłat publicznych, [w:] R. Mastalski, E. Fojcik-Mastalska (red.), Prawo finansowe, Warszawa 2013.

3. Kosikowski C., [w:] C. Kosikowski. L. Etel, J. Brolik, R. Dowgier, P. Pietrasz, M. Popławski, S. Presnarowicz S., Stachurski W., Ordynacja Podatkowa. Komentarz, Warszawa 2013.

4. Mastalski R., Tworzenie prawa podatkowego a jego stosowanie, Warszawa $2016 \mathrm{r}$.

5. Ruśkowski E., Salachna J.M., Ustawa o dochodach jednostek samorzadu terytorialnego. Komentarz, Warszawa

Klaudia Stelmaszczyk, Regionalna Izba Obrachunkowa w Opolu, Główna Komisja Orzekająca w Sprawach o Naruszenie Dyscypliny Finansów Publicznych, Państwowa Wyższa Szkoła Zawodowa im. Angelusa Silesiusa w Wałbrzychu 